Innovation of Vocational Technology Education

Available online at http://ejournal.upi.edu/index.php/invotec

\title{
V
}

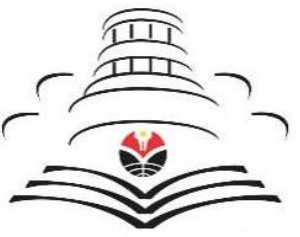

JURNAL UPI

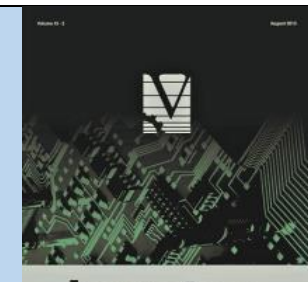

invotec

\section{Employability Skills in Technical Vocational Education and Training (TVET)}

Hari Din Nugraha, R. A. Vesitara Kencanasari, Reni Nuril Komari, and Kasda Universitas Pendidikan Indonesia, Bandung, Indonesia

\section{ARTICLE INFO}

Article history:

Received: 02 October 2019

Received in revised form: 25 November 2019

Accepted: 15 January 2020

Available online: 29 February 2020

Keywords:

employability skills;

TVET;

framework

Authors email:

haridinnugraha@upi.edu
A B S T R A C T

\begin{abstract}
Employability skills should be a necessity for every TVET graduate. The need for the employability skills is very important in order to prepare TVET graduates in entering the labor market. The purpose of this study is: (1) to verify indicators of employability skills needed by TVET graduates and, (2) to produce proposals for employability skills frameworks for TVET graduates. This article reviews various relevant literature in order to explore the needs of appropriate employability skills. The results of the literature review show the employabilty skills needed by TVET sorted according to rank, namely; Social Skills, Knowledge in the Field of Engineering, Communication Skills, Information and Technology Skills, Management Skills, Creative and Innovative, Problem Solving and Critical Thinking. The implications of this literature review provide information and recommend a set of frameworks for academics to improve the employability skills of TVET graduates.
\end{abstract}

\section{Introduction}

Employability skills become an international concept even though they come with such various names as generic skills, employability skills, key skills, core skills and others. However, they basically share the same core notion which is the ability that tends to lead more to nontechnical skills (Bridgstock, 2009). The application of employability skills is to ensure that someone gets the opportunity to get employability skills, job maintenance and work efficiency needed (Sermsuk, Triwichitkhun, \& Wongwanich, 2014). The impact could be an economic downturn for a country (Saunders \& Zuzel, 2010). These problems can be an emergency and occur if someone is unable to get a job. Later, it will be a contributor to economic decline for a country because the effect is caused by a lack of employability skills.

Every candidate's worker and worker must have good employability skills due to technological change and increasing globalization with strong competitiveness. Companies desire graduates who are technically competent and also equipped with relevant employability skills 
(Pitan, 2016). Employability skills are work skills that refer to general or non-technical competencies including achievement, understanding and personal attributes that make an individual able to get a job and become successful in his chosen job (Ju, Zhang, \& Pacha, 2012; Mello et al., 2017). Implicitly, Employability skills mean that skills can be transferred as well as basically the ability to increase efficiency in work (Simatele, 2015). Employability skills are also a guide on how to get jobs according to their professional field qualifications, thereby increasing the attractiveness of being recruited by companies (Cavanagh et al., 2015). Therefore, workers can survive in their jobs and reach a top career in their field work.

Employability skills are verified into seven skills that are considered important by industry, namely; foundation skills; (basic skills, thinking skills, personal quality) and workplace competencies; (resources, interpersonal, information, system, technology) (Digest et al., 2000). More specifically, personal skills are skills that can be a means of working with others (Spinks, Silburn, \& Birchall, 2007). Communication skills are needed by graduates because every job requires initiative, flexibility, and one's ability to accept different tasks (Hanafi, 2014). these skills allow someone to be able to read the opportunity to succeed in because it has a good effect on how a person works (Kazilan, Hamzah, \& Bakar, 2009; Sisodia \& Agarwal, 2017).

Employability skills can be obtained through training and skills in industrial internships as if they are working in an industrial situation (Kazilan, Hamzah, \& Bakar, 2009). Employability skills should be a must for every graduate. Integrating employability skills in learning is expected to produce graduates who are ready to be recruited by the company. Educational institutions as providers of graduates must respond quickly to any changes employabiliy skills that have the knowledge, skills that are in accordance with the requirements that are demanded by the industry.

This study focuses on reviewing the most essential literature findings of the employability skills attributes for TVET graduates. This is crucial and important to do further research. As an appropriate step option, by identifying and verifying from finding employability skills indicators that are considered important and strategic for graduates, so they can be absorbed more by the industry.

In addition, the result of these research will be a framework which can be a proposal and reference material as an anticipation steps in TVET curriculum preparation to students who will enter the workforce.

The objectives of this study are: (1) to verify indicators of employability skills needed by TVET graduates; (2) to produce employability skills frameworks proposal for TVET graduates. The data will be reviewed from the available various literature in order to obtain the relevant and appropriate employability skills need. 


\section{Methods}

The study searched about 120 journals, the majority of which were in Employability skills and Technical Vocational Education \& Training which collected and grouped to be combine. The process of finding literature was carried out from web science data that have a huge repository through Scopus, science direct, Taylor \& Francis, Sage Journals and Springer. The papers were taken in between November and December and were limited to ones published from 2006 to 2018. The articles were searched using such keywords as "employability skills", "generic skills", "framework", "Technical vocational and Training", and "industry 4.0" which were used to expand and ease the literature search process. Here presented in Table 1 the frequency for sorting out journals.

Table 1. The frequency of keyword in the journal paper

\begin{tabular}{lll}
\hline No & Keyword & Frequency \\
\hline 1 & Employability skills & 62 \\
2 & Generic skills & 12 \\
3 & TVET & 19 \\
4 & Framework & 7 \\
5 & Industry 4.0 & 20 \\
\hline & Total & 120 \\
\hline
\end{tabular}

The articles were then read thoroughly and partially in order to make them easier to be tormented and grouped. Furthermore, irrelevant articles were eliminated and accordingly separated according to needs. From this stage, as many as 60 relevant articles were acquired. All the 60 articles were then analyzed whether they focus on employability skills that are oriented in TVET or not.

The articles were analyzed by reviewing what the research focus was, the scope of the problem under study, where the research focused on, and how the research results were. These findings are conceptualized into a literature review that has novelty value (Hsieh \& Shannon, 2005). Then the articles were explored and combined in a literature review form (Stepchenkova, Kirilenko, \& Morrison 2008). The discussion sections, criticized by providing visionary ideas to answer the purpose of literature that contributes insight to the reader. A relevant article from 2006 to 2018 were analyzed and summarized as shown in the example of Table 2. 
Table 2. Example summary of journal review

\begin{tabular}{|c|c|c|c|c|}
\hline Study & Participant & Context & Type of Data & Basic Finding \\
\hline $\begin{array}{l}\text { Track Dining } \\
\text { (2017) } \\
\text { “Embedding } \\
\text { employability } \\
\text { and enterprise } \\
\text { skills in sports } \\
\text { degrees } \\
\text { through a } \\
\text { focused - } \\
\text { based project a } \\
\text { student and } \\
\text { employer } \\
\text { viewpoint” }\end{array}$ & $\begin{array}{l}30 \\
\text { undergraduate } \\
\text { students and } 5 \\
\text { industrial } \\
\text { projects (United } \\
\text { Kingdom) }\end{array}$ & $\begin{array}{l}\text { The project } \\
\text { based learning } \\
\text { experience is } \\
\text { carried out for } \\
10 \text { days by } \\
\text { undergoing an } \\
11 \text {-week } \\
\text { university } \\
\text { Sports } \\
\text { Business } \\
\text { semester } \\
\text { program }\end{array}$ & $\begin{array}{l}\text { Mix-method } \\
\text { Questionnaire } \\
\text { using iPad and } \\
\text { online survey tools. } \\
\text { Interviews with } \\
\text { students and } \\
\text { industry. }\end{array}$ & $\begin{array}{l}\text { Students lack } \\
\text { understanding how to } \\
\text { apply skills in the } \\
\text { context of sports } \\
\text { organizations and are } \\
\text { seen as an industry } \\
\text { able to develop about } \\
\text { their abilities }\end{array}$ \\
\hline
\end{tabular}

\section{Results and Discussion}

In general, employability skills are very important for TVET graduates. The skills of employability skills are seen as a necessity that is provided to every TVET graduate. This skill will provide long-term effects when the graduates work later. These skills will lead them to successful work in their respective fields of expertise. The company considers that employability skills are a skill that is the most important and is also assumed to be able to contribute to the company development (Markes, 2006).

The findings show that some indicators of employability skills are very important for TVET graduates. The industry considers that the most desirable graduate attributes are social skills, knowledge in the fields of engineering, communication skills, technology and information skills, management skills, creative and innovative, problem solving and critical thinking. This indicates that TVET graduates, in addition to having educational qualifications in their respective fields, must also still have a social nature and interpersonal abilities. Whereas, their technical skills can continue to be deepened in the industry where they work (Lee \& Chin, 2016). TVET graduates can be flexible and quickly adaptable in a new work environment. These findings had a huge impact to the graduates who have an implication that there are other factors sought by the industry in recruiting workers. In the table 3 it is presented more specifically and relevantly from the latest research on employability skills indicators. 
Table 3. Employability skills framework for TVET

\begin{tabular}{|c|c|c|}
\hline No & Source & Employability skills indicator \\
\hline 1 & Interpersonal Skills & $\begin{array}{l}\text { Ghazali \& Bennett (2017); Dinning (2017); De Cuyper et } \\
\text { al. (2012); Ahmed et al. (2012); Smith, Maguire, \& Han } \\
\text { (2018); Stoner \& Milner (2010) }\end{array}$ \\
\hline 2 & Knowledge of Technical & $\begin{array}{l}\text { Saunders \& Zuzel (2010); Palmer (2009); Schech et al. } \\
\text { (2017); Washer (2007); Watkins \& Smith (2018); Drange, } \\
\text { Bernstrøm, \& Mamelund (2018); Markes (2006) }\end{array}$ \\
\hline 3 & ICT Skills & $\begin{array}{l}\text { Knox \& Stone (2018); Chan et al. (2018); Pérez-Ortiz, \& } \\
\text { Ruesga-Benito (2018); Simatele (2015); Buunaaisie et al. } \\
\text { (2017) }\end{array}$ \\
\hline 4 & Communication & $\begin{array}{l}\text { Suleman (2018); Adeyinka-Ojo (2018); Yuzainee, } \\
\text { Zaharim, \& Omar (2011); Deeley (2014) }\end{array}$ \\
\hline 5 & Management Skills & $\begin{array}{l}\text { Lim et al. (2016); Hordósy, Clark, \& Vickers (2018); } \\
\text { Keller, Parker, \& Chan (2011) }\end{array}$ \\
\hline 6 & Creative and Innovative & Higdon (2018); Sardana \& Arya (2003) \\
\hline 7 & $\begin{array}{l}\text { Problem solving and } \\
\text { Critical Thinking }\end{array}$ & Ismail \& Mohammed (2015); Hammer et al. (2018) \\
\hline
\end{tabular}

The ideal figure of TVET graduates must be flexible to the job market needs, that is why the market needs the employability skills attributes considered most relevant by TVET graduates to become a priority of the company's choice in recruiting workers. The result of the research shows that the industry agreed that there are seven employability skills; interpersonal skills, thinking skills, personal qualities, resource skills, ICT skills, basic skills, and information skills (Rasul et al., 2012). This is related to the employability skills survey that are considered important by the manufacturing industry, namely; communication skills, problem solving skills, adaptive skills, interpersonal skills and the ability to work as a team, organizational and personal management skills, management skills, English language skills, leadership skills and ICT skills (Chan et al., 2018).

In addition to generic employability skills, there must be technical skills that are used as basic fundamentals that will provide changes in a mastery of technology (Spinks, Silburn, \& Birchall, 2007). Technical skills are specialized work and basic academic skills, these skills are further classified as science (Misra \& Khurana, 2017). These technical skills must be in accordance with the qualification standards in their respective countries. In Indonesia, there are special standards for several TVET graduates, namely Qualification Indonesian Framework or KKNI, such as electrical engineering, civil engineering, automotive, culinary, fashion, and cosmetology engineering. Furthermore, from one more specific expertise divided into several skill schemes, for example, machine operators.

Furthermore, the company is very interested in graduates who can develop their company. For this reason, each worker ideally has good verbal communication skills. In the world of work, communication is needed in the effort of coordination, instruction, and information back. Without good communication it will have implications for miss communication in receiving information. Therefore, communication is considered important in order to unite perceptions between workers. 
This if it goes well can improve the performance of workers which will have an impact on the development of company productivity.

Research results show that personality also plays an important role in a corporate environment (Ahmed et al., 2012). Environmental culture in a company will produce comfort in work. Personal and social skills are closely related to skills related to fellow humans and the skills of managing tasks or work. Personality has a relationship with one's motivation and culture (Rodzalan \& Saat, 2012). For example, the employee ethics are given a job desk by the boss if the worker has good response, then he will have a tendency to work with full motivation and awareness. That way, the boss becomes satisfied because the worker is because he has a good quality performance at work. So that it will automatically affect the progress of his career, even more broadly to maintain jobs in his field (Drange, Bernstrøm, \& Mamelund, 2018).

In some large companies, workers who have critical thinking are needed to face the problem being faced by the company. There are so many problems, conflicts that can occur from companies. Critical thinking is very helpful for a company, thus contributing successfully to the company's strategic direction (Clayton et al., 2004). By having problem-solving competencies and analytical thinking will later have an impact on making a quick and appropriate decision. TVET graduates should ideally be able to adapt quickly to these skills because they have felt an internship at work first, so that it helps apply and practice knowledge effectively at work later (Zaharim, Yusoff, \& Omar, 2009).

Meanwhile, IT skills and use of technology in the company have become a must for every worker. The company has switched to the concept of a smart factory model or industry 4.0. The digitization process in the production flow is very helpful in efficient time. The rasionation has become a necessity for TVET graduates to be able to respond to technological changes that are developing by using them in the society of digital culture (Nonthacumjane, 2011; Schech et al., 2017). In line with that, every worker must be able to choose and use the technology that will be used so that it can help his work.

In modern industries like this, it is a priority that companies recruit workers who have creative and innovative skills (Wickramasinghe \& Perera, 2010). Workers are required to think creative and innovative so as to produce an idea, the idea and novelty can bring dynamic changes to the company progress. Therefore, it could just as slow to innovate, the company becomes displaced by competition with other companies. This is what causes the consequence that company people must be filled with creative and innovative workers.

Everyday activities carried out by workers always require that there be a deadline work system (Rowley, 2014). In balancing a busy schedule, such as sports, work shifts and rest. In a company or organization, this capability can be felt useful for the continuity of a company (Rothwell \& Arnold, 2007). Because workers who have good self-discipline will have an effect on work productivity (Orner, 2009). This work productivity will bring a domino effect to the sustainability of the company itself. The quality of self-discipline is certainly a climax of the corporate climate that 
improves the quality of self-discipline. Implicitly, skills are seen as work capabilities that are considered important (Dinning, 2017).

\section{Conclusion}

This literature review helps in recommending a list of employability skills needed by TVET graduates. The attributes are taken from several research results that have been verified by experts. The implications of this study will help academics in recommending a set of employability skills that are prioritized by industry. In the future, academics need to prioritize the contents of employability skills to highlight the gap between the skills they have and the skills needed by the industry, so that they can be a solution to minimize the employability skills gap.

The importance of working skills needs to be realized by academics. The companies have set criteria for the desired standard. Many factors also affect employability skills such as gender, work experience in self motivation, and demography. From this review, it is necessary to have comprehensive and dynamic changes in order to form the contents of high employability skills. In the middle of extracurricular activities in TVET can be integrated with the training that forms characters such as self-management, leadership, social skills, and problem solving.

The good quality of employability skills greatly influences the sustainability of his career development in working. These employability skills directly provide a positive charge so that TVET graduates can adapt quickly and grow their work readiness. This can be explained between the needs of the workforce and the expected skills desired by the company.

\section{References}

Adeyinka-Ojo, S. (2018). A strategic framework for analysing employability skills deficits in rural hospitality and tourism destinations. Tourism Management Perspectives, 27(April), 47-54.

Ahmed, F., Capretz, L. F., Bouktif, S., and Campbell, P. (2012). Soft skills requirements in software development jobs: A cross-cultural empirical study. Journal of Systems and Information Technology, 14(1), 58-81.

Bridgstock, R. (2009). The graduate attributes we've overlooked: Enhancing graduate employability through career management skills. Higher Education Research and Development, 28(1), 31-44.

Buunaaisie, C., Manyara, A. M., Annett, H., Bird, E. L., Bray, I., Ige, J., ... and Evans, D. (2018). Employability and career experiences of international graduates of MSc Public Health: a mixed methods study. Public Health, 160, 62-69.

Cavanagh, J., Burston, M., Southcombe, A., and Bartram, T. (2015). Contributing to a graduatecentred understanding of work readiness: An exploratory study of Australian undergraduate students' perceptions of their employability. International Journal of Management Education, 13(3), 278-288. 
Chan, C. K. Y., Fong, E. T. Y., Chan, C. K. Y., and Fong, E. T. Y. (2018). Disciplinary differences and implications for the development of generic skills: a study of engineering and business students perceptions of generic skills. European Journal of Engineering Education, 0(0), 1-23.

Clayton, B., Blom, K., Meyers, D., and Bateman, A. (2004). Assessing and certifying generic skills. Generic Skills in Vocational Education and Training: Research Readings, 157-172.

De Cuyper, N., Raeder, S., Van der Heijden, B. I. J. M., and Wittekind, A. (2012). The association between workers' employability and burnout in a reorganization context: Longitudinal evidence building upon the conservation of resources theory. Journal of Occupational Health Psychology, 17(2), 162-174.

Deeley, S. J. (2014). Summative co-assessment: A deep learning approach to enhancing employability skills and attributes. Active Learning in Higher Education, 15(1), 39-51.

Digest, T., Created, W. A. S., Eric, B. Y., and Resources, T. H. E. E. (2000). Skills: An Update. ERIC Digest No . 220 . Employability Skills : An Update . ERIC Digest. (220), 1-8.

Dinning, T. (2017). Embedding employability and enterprise skills in sport degrees through a focused work - based project; a student and employer viewpoint. Cogent Education, 4(1), $1-14$.

Drange, I., Bernstrøm, V. H., and Mamelund, S. E. (2018). Are You Moving Up or Falling Short? An Inquiry of Skills-based Variation in Self-perceived Employability among Norwegian Employees. Work, Employment and Society, 32(2), 387-406.

Ghazali, G., and Bennett, D. (2017). Employability for music graduates: Malaysian educational reform and the focus on generic skills. International Journal of Music Education, 35(4), 588-600.

Hammer, S., Abawi, L., Gibbings, P., Jones, H., Redmond, P., and Shams, S. (2018). Developing a generic review framework to assure capstone quality. Higher Education Research and Development, 37(4), 730-743.

Hanafi, I. (2014). Pendidikan Teknik dan Vokasional. Bandung: PT Refika Aditama.

Higdon, R. D. (2018). From employability to 'complexability.' Industry and Higher Education, 32(1), 33-46.

Hordósy, R., Clark, T., and Vickers, D. (2018). Lower income students and the 'double deficit' of part-time work: undergraduate experiences of finance, studying and employability. Journal of Education and Work, 00(00), 1-13.

Hsieh, H. F., and Shannon, S. E. (2005). Three approaches to qualitative content analysis. Qualitative health research, 15(9), 1277-1288.

Ismail, S., and Mohammed, D. S. (2015). Employability Skills in TVET Curriculum in Nigeria Federal Universities of Technology. Procedia - Social and Behavioral Sciences, 204(November 2014), 73-80.

Ju, S., Zhang, D., and Pacha, J. (2012). Employability Skills Valued by Employers as Important for Entry-Level Employees With and Without Disabilities. Career Development for Exceptional Individuals, 35(1), 29-38. 
Kazilan, F., Hamzah, R., and Bakar, A. R. (2009). Employability Skills Among the Students of Technical and Vocational Training Centers in Malaysia. European Journal of Social Sciences, 9(1), 147-160.

Keller, S., Parker, C. M., and Chan, C. (2011). Employability skills: Student perceptions of an is final year capstone subject. ITALICS Innovations in Teaching and Learning in Information and Computer Sciences, 10(2).

Knox, J., and Stone, M. (2018). Embedding employability skills for the legal professionals of the future. The Law Teacher, 00(00), 1-12.

Lee, C. C., and Chin, S. F. (2016). Engineering Students' Perceptions of Graduate Attributes: Perspectives From Two Educational Paths. IEEE Transactions on Professional Communication, 60(1), 42-55.

Lim, Y. M., Lee, T. H., Yap, C. S., and Ling, C. C. (2016). Employability skills, personal qualities, and early employment problems of entry-level auditors: Perspectives from employers, lecturers, auditors, and students. Journal of Education for Business, 91(4), 185-192.

Markes, I. (2006). A review of literature on employability skill needs in engineering. European Journal of Engineering Education, 31(6), 637-650.

Mello, L. V., Tregilgas, L., Cowley, G., Gupta, A., Makki, F., Jhutty, A., and Shanmugasundram, A. (2017). 'Students-As-Partners' scheme enhances postgraduate students' employability skills while addressing gaps in bioinformatics education. Higher Education Pedagogies, 2(1), 43-57.

Misra, R. K., and Khurana, K. (2017). Employability Skills among Information Technology Professionals: A Literature Review. Procedia Computer Science, 122, 63-70.

Nonthacumjane, P. (2011). Key skills and competencies of a new generation of lis professionals. IFLA Journal, 37(4), 280-288.

Orner, M. M. (2009). Employability Skill Acquisition of Career and Technical Education Students. Doctoral dissertation, US: Duquesne University.

Palmer, R. (2009). Skills development, employment and sustained growth in Ghana: Sustainability challenges. International Journal of Educational Development, 29(2), 133-139.

Picatoste, J., Pérez-Ortiz, L., and Ruesga-Benito, S. M. (2018). A new educational pattern in response to new technologies and sustainable development. Enlightening ICT skills for youth employability in the European Union. Telematics and Informatics, 35(4), 10311038.

Pitan, O. S. (2016). Towards Enhancing University Graduate Employability in Nigeria. Journal of Sociology Anthoropology, 7(1), 1-11.

Rasul, M. S., Abd Rauf, R. A., Mansor, A. N., and Puvanasvaran, A. P. (2012). Employability skills assessment tool development. International Education Studies, 5(5), 43-56.

Rodzalan, S. A., and Saat, M. M. (2012). The Effects of Industrial Training on Students' Generic Skills Development. Procedia - Social and Behavioral Sciences, 56(Ictlhe), 357-368.

Rothwell, A., and Arnold, J. (2007). Self-perceived employability: Development and validation of a scale. Personnel review.

Rowley, C. (2014). Student and employer perceptions of the importance of entry-level employability skills. Doctoral dissertation. 
Sardana, H. K., and Arya, P. P. (2003). Training effectiveness of engineering students: a case study. European journal of engineering education, 28(1), 59-69.

Saunders, V., and Zuzel, K. (2010). Evaluating Employability Skills: Employer and Student Perceptions. Bioscience Education, 15(1), 1-15.

Schech, S., Kelton, M., Carati, C., and Kingsmill, V. (2017). Simulating the global workplace for graduate employability. Higher Education Research and Development, 36(7), 1476-1489.

Sermsuk, S., Triwichitkhun, D., and Wongwanich, S. (2014). Employment Conditions and Essential Employability Skills Required by Employers for Secondary School Graduate. Procedia Social and Behavioral Sciences, 116, 1848-1854.

Simatele, M. (2015). Enhancing the portability of employability skills using e-portfolios. Journal of Further and Higher Education, 39(6), 862-874.

Sisodia, S., and Agarwal, N. (2017). Employability Skills Essential for Healthcare Industry. Procedia Computer Science, 122, 431-438.

Smith, B., Maguire, W., and Han, H. H. (2018). Generic skills in accounting: perspectives of Chinese postgraduate students. Accounting and Finance, 58(2), 535-559.

Spinks, N., Silburn, N. L. J., and Birchall, D. W. (2007). Making it all work: the engineering graduate of the future, a UK perspective. European Journal of Engineering Education, 32(3), 325-335.

Stepchenkova, S., Kirilenko, A. P., and Morrison, A. M. (2008). Facilitating Content Analysis in Tourism Research. Journal of Travel Research, 47(4), 454-469.

Stoner, G., and Milner, M. (2010). Embedding generic employability skills in an accounting degree: Development and impediments. Accounting Education, 19(1-2), 123-138.

Suleman, F. (2018). The employability skills of higher education graduates: insights into conceptual frameworks and methodological options. Higher Education, 76(2), 263-278.

Washer, P. (2007). Revisiting key skills: A practical framework for higher education. Quality in Higher Education, 13(1), 57-67.

Watkins, H., and Smith, R. (2018). Thinking Globally, Working Locally: Employability and Internationalization at Home. Journal of Studies in International Education, 22(3), 210224.

Wickramasinghe, V., and Perera, L. (2010). Graduates', university lecturers' and employers' perceptions towards employability skills. Education and Training, 52(3), 226-244.

Yuzainee, M. Y., Zaharim, A., and Omar, M. Z. (2011). Employability skills for an entry-level engineer as seen by Malaysian employers. 2011 IEEE Global Engineering Education Conference, EDUCON 2011, (June 2014), 80-85.

Zaharim, A., Yusoff, Y., and Omar, M. (2009). Engineering Employability Skills Required By Employers In Asia. Proceedings of the 6th WSEAS International Conference on ENGINEERING EDUCATION Engineering, 6(9), 195-201. 